\title{
ВІКТИМОЛОГІЧНІ ЗАХОДИ ЗАПОБІГАННЯ СЕКСУАЛЬНІЙ ЕКСПЛУАТАЦІї ДИТИНИ
}

\author{
МИСКОВА Ганна Миколаївна - здобувач кафедри кримінально-правових \\ дисциплін та судових експертиз Донецького юридичного інституту МВС України \\ DOI:10.32782/LAW.2019.3.15 \\ УДК 343.9:343.54
}

У статті розглянуті віктимологічні питання запобігання сексуальній експлуатацій дітей. Наголошено на бакторі віктимності, що полягає у здатності потениійних жертв у конкретних життевих обставинах стати об'єктом злочинного впливу, зазнали фізичних, матеріальних та моральних втрат. З’ясовано, що заходи віктимологічного запобігання сексуальній експлуатаиій щодо дітей повинні включати можливості інформачійного впливу на молодіжне середовище з пропагуванням здорового способу життя, проведення иільових пробілактичних поліцейсъких заходів, що в комплексі спрямовані на запобігання віктимізацї груп неповнолітніх, а також включати індивідуальну роботу з дітьми, які постраждали від сексуального насильства. Виокремлено борми здійснення психопробілактичної роботи, шо мають віктимологічне значення.

Ключові слова: сексуальна експлуатація; віктимологія; жертва; дитина; запобігання.

Прискорення процесів європейської інтеграції України потребує впровадження у правоохоронну практику не лише сучасних форм і методів протидії злочинності, а й визнаних світовим співтовариством стандартів захисту прав і свобод людини. Реальні демократичні перетворення є невід'ємними від гуманізації соціальних відносин, адже людина, іiї життя і здоров'я, честь та гідність, недоторканність і безпека визнаються найвищою соціальною цінністю. початку XXI ст. впливає декілька груп чинників, зокрема наслідки демонтажу соціалістичної моделі розвитку країни (зростання соціальної незахищеності, втрата ціннісних орієнтирів, різке зниження рівня життя, збільшення маргінальної маси за рахунок безробітних, бездомних та інших категорій населення, які перебувають за межею бідності); складна соціально-політична ситуація (військові дії у східних областях, покращення технічної оснащеності злочинців, зростання рівня нетерпимості, девальвація морально-правових цінностей); вплив тенденцій глобалізованого світу (аномізація суспільства на рівні глибинних параметрів існування та відтворення соціуму; посилення міграційних процесів та позицій транснаціональної організованої злочинності), що в комплексі створюють підгрунтя для виникнення нових типів кримінальних загроз для населення і, відповідно, сприяють його інтенсивній віктимізації [1].

Ужиті правоохоронними та іншими державними органами заходи не дали можливості нейтралізувати основні внутрішні та зовнішні загрози національній безпеці, що зумовлюють подальше ускладнення криміногенної ситуації в державі в умовах гібридної війни. Так, за останні десять років рівень злочинності зріс більше ніж у чотири рази, зокрема збільшилася питома вага найнебезпечніших іiі проявів. Зокрема, у 2018 році кількість громадян, які стали жертвами кримінальних посягань, збільшилася на 
9,0 \% та становила 400,7 тис. (у 2017 році - 366,3 тис.). Серед потерпілих від злочинів майже 156,8 тис. жінок, 29,2 тис. пенсіонерів, 5,8 тис. дітей, 1,8 тис. іноземців, 194 працівники засобів масової інформації. Понад 5,6 тис. осіб загинуло. Найбільш незахищеними верствами населення залишаються жінки та діти (за 2013-2018 роки збільшилася майже на чверть кількість протиправних діянь за ст.ст. 149, 152-156, 301-303 Кримінального кодексу України), а також особи похилого віку, щодо яких у 2018 році вчинено на 5,3 \% більше кримінальних правопорушень, ніж у попередні періоди [2; 3].

Зазначене свідчить про низький рівень ефективності превентивних заходів у сфері протидії злочинності. Пошук нових (альтернативних) методів запобігання злочинам усе частіше орієнтує кримінологів на проблеми жертви суспільно небезпечних діянь, чинники, що визначають здатність окремих осіб та ïх груп у певних ситуаціях ставати об'єктом посягань, учинених з різних мотивів.

Проблеми віктимізації [4, с. 27] тісно пов'язані 3 питаннями забезпечення безпеки, передусім іï виду - віктимологічної безпеки [5, с. 38]. Головним засобом забезпечення віктимологічної безпеки є віктимологічне запобігання злочинам. Забезпечити безпеку громадян і суспільства від первинної чи рецидивної віктимності дозволяють два види діяльності: девіктимізація та віктимологічне запобігання злочинам, з яких перший становить сутність і головну мету другого.

Метою девіктимізації як головного способу віктимологічного запобігання злочинам [6, с. 115] є повноцінна ресоціалізація потерпілих від злочинів, зниження віктимності потенційних жертв, запобігання рецидивній віктимізації і встановлення соціальної справедливості.

Необхідним елементом системи віктимологічного запобігання злочинам, девіктимізації є забезпечення високого рівня віктимологічної безпеки особи (кожної людини) через систему соціальної адаптації (соціалізації).

Соціологія як загальногуманітарна наука намагається лише окреслити коло ознак соціалізації, що визначається як процес фор- мування соціальних якостей, властивостей, цінностей, знань і вмінь, за допомогою яких людина (індивід) стає дієздатним учасником соціальних зв'язків, інститутів і суспільства. У віктимологічному плані завдань соціалізації є девіктимізація, тобто формування антивіктимологічних якостей, властивостей, цінностей, знань і вмінь. У суспільстві посилена соціалізація є гарантією зниження загального рівня напруження, страху і віктимності, а отже, і зниження (гальмування) темпів зростання рівня злочинності.

Умовами успішної профілактичної роботи вважають їі комплексність, послідовність, диференційність, вчасність. Остання умова особливо важлива в роботі з активно формуючою особою, наприклад підлітком.

У спеціальній літературі [7, с. 115] виокремлено декілька форм здійснення психопрофілактичної роботи, що мають віктимологічне значення.

Перша форма - організація соціального середовища. Вплив може бути спрямований на суспільство загалом, через створення негативної громадської думки щодо девіантної поведінки. Об'єктом роботи може бути сім'я, соціальна група, конкретна особа. Особливе значення має політика засобів масової інформації. Спеціальні програми, виступи молодіжних кумирів, спеціально підібрані кінофільми - все це повинно мати якісно новий рівень, ніж те, що нині спостерігаємо.

у межах даного підходу здійснюються спроби створення антивіктимогенних «зон», що не сумісні 3 віктимогенною поведінкою [8, с. 116].

Друга форма психопрофілактичної роботи - інформування. Це найбільш відомий напрям профілактичної роботи у формі лекцій, бесід, розповсюдження спеціальної літератури чи відео- і телефільмів.

Перспективному розвитку даного підходу може сприяти відмова від інформації, яка залякує, а також диференціація інформації за статевими ознаками, віком, соціальноекономічними характеристиками.

Третя форма психопрофілактичної роботи 3 девіктимізації - активне навчання соціально важливим навичкам. Така модель насамперед реалізується у формі групових тренінгів. 


\section{Кримінальне право, кримінальний процес та криміналістика}

Четверта форма - організація діяльності, альтернативної віктимній поведінці. Ця форма роботи пов'язана з уявленнями про чудовий ефект девіантної поведінки. Аюди використовують віктимні форми поведінки доти, доки не отримають взамін щось краще. Альтернативними формами активності є пізнання (мандрування), випробування себе (походи в гори), спілкування, любов, творчість, діяльність (у тому числі професійна, благодійна, релігійно-духовна тощо).

П'ята форма - організація здорового способу життя. Здоровий спосіб життя передбачає здорове харчування, регулярні фізичні навантаження, дотримання режиму праці і відпочинку.

Шоста форма - активізація особистих ресурсів. Активні заняття спортом, творче самовираження, участь у групах спілкування - усе це активізує особисті ресурси, які забезпечують безпеку особи, іiї здоров'я і стійкість до віктимізації.

Сьома форма - мінімізація негативних наслідків віктимної поведінки, що спрямовані на профілактику рецидивів або їх негативних наслідків.

Діти, безумовно, є найбільш незахищеною та вразливою частиною населення. Вони повністю залежать від дорослих. Діти, як і дорослі, стають жертвами фізичного, сексуального й психологічного насильства.

Насильство над дітьми - це проблема, що викликає серйозну стурбованість міжнародного суспільства. Це широке поняття, яке включає різні види поведінки батьків та опікунів, інших родичів, учителів, вихователів, будь-яких осіб, які старші або сильніші. Жорстоке поводження 3 дітьми і зневага їх інтересів можуть мати різні види і форми, але вони завжди спричиняють значну шкоду здоров'ю, розвитку і соціалізації дитини, нерідко - загрожують їі життю або призводять до смерті.

Соціальна профілактика злочинності повинна грунтуватися на наукових дослідженнях чинників ризику сексуального насильства, одним 3 яких є агресивна поведінка в дитячому віці, сексуальне насильство відносно дітей та емоційна нестриманість у сім'ї. Отже, першочерговим завданням соціальної профілактики постає проблема сімейної кримінології, втручання на ранньому етапі в сім'ї з ризиком жорстокого поводження 3 дітьми, які зловживають алкоголем, наркотичними і психотропними засобами, з метою забезпечення психологічної і медичної підтримки та допомоги.

Проблема насильства над дітьми та його наслідків посідає важливе місце серед інших актуальних проблем міжнародної кримінологічної науки. Безперечно, вона далека від вирішення і вимагає нових дослідницьких програм, оригінальних методологічних підходів і пильної уваги до специфіки психотерапевтичної та психокорекційної роботи 3 дітьми, які пережили подібний досвід. Необхідність більш грунтовного дослідження цієї проблеми, зокрема сексуального насильства над дітьми та його наслідків, зумовила актуальність даної роботи.

Сексуальне насильство - використання дитини дорослою або іншою дитиною для задоволення сексуальних потреб, або з корисливою метою. Сексуальне насильство включає в себе статеве знущання, оральний і анальний секс, взаємну мастурбацію, інші тілесні контакти із статевими органами. До сексуального розбещення належать також залучення дитини до проституції, порнобізнесу, оголення перед дитиною статевих органів і сідниць, підглядання за нею, коли вона про це не здогадується: під час роздягання, справляння природних потреб.

Численні дослідження щодо осіб, які вчинили протиправні сексуальні дії стосовно дітей, доводять, що винні самі в дитинстві піддавалися сексуальному насильству, тобто виявляється спадкоємність поведінки (зворотна реакція). Американські вчені, дослідивши 747 осіб, які вчинили сексуальні злочини, виявили, що $76 \% 3$ них у дитинстві самі піддавалися сексуальному насильству, отже, утворюється кримінальне коло, або цикл «victim-to-victimizer» [9].

У зв’язку з цим, І. С. Кон зазначає: «Деякі сексуально травмовані діти, ставши дорослими, відрізняються від інших зниженням самоповаги, гіпертрофованим відчуттям вини і сорому, відчуттям відчуження від інших, схильністю до алкоголізму і наркоманії» [10, с. 64-66]. 
Доведено, що діти, які відчували на собі жорстокість та сексуальне насильство, підсвідомо прагнуть відтворити свій життєвий досвід у дорослому житті, оскільки не знають іншої моделі поведінки. Віддаленими наслідками насильства є схильність до наслідування: адитивна, девіантна, делінквентна та асоціальна поведінка.

В Україні сексуальне насильство над дітьми, дитяча проституція і порнографія тісно пов'язані із соціально-економічними та культурними особливостями регіонів. Так, наявність курортів і портів на півдні нашої держави, де, до речі, ранне статеве життя вже давно стало традицією, тільки стимулює поширення проблеми. На сході, через високий рівень безробіття і цілу низку соціально-економічних труднощів, експерти також констатують «розквіт» розпусти. На півночі України - низькі соціально-економічні показники, а також близькість столиці тільки підвищує ризик утягування дітей у секс-індустрію. Тільки західним областям 3 їхньою низькою щільністю населення i високим рівнем релігійності вдається стримувати поширення цього явища. Водночас йому сприяють низький рівень зайнятості населення в регіоні й трудовий міграційний процес.

У більшій частині досліджень розглянуто такі механізми, як ідентифікація з агресором і вираження своєї образи на іншому; дитина, яка піддається насильству, незважаючи на страх і біль, отримує при цьому сексуальне збудження, обставини якого залишаються в ії уяві, роблячи для неї привабливим аналогічний сексуальний контраст 3 хлопчиками [11, с. 66].

Проте, на наш погляд, дії сексуальної психотравми як причини кримінальної поведінки необхідно розглядати, зважаючи на сукупність заподіяної шкоди та ситуаційні особливості реалізації кримінальної поведінки. Правові норми, насамперед у сфері кримінального законодавства, залишаються такими, що визначають демаркаційну лінію, тому від того, наскільки чітко будуть визначені критерії і якими вони будуть за своїм змістом, залежатимуть соціальні, культурні і психологічні аспекти взаємозв'язку дитинства і дорослого віку.
До заходів профілактичного впливу стосовно неповнолітніх має належати й робота в неблагополучних сім'ях, де вони піддаються знущанню, розтлінному впливу дорослих. Утручання в долю підлітка може бути пов'язано з кардинальною зміною умов його життя. 3 метою активізації захисних можливостей неповнолітніх їх слід інформувати про служби психологічної допомоги жертвам насильства, у тому числі й сімейного типу.

Оскільки багато злочинів щодо неповнолітніх пов'язані з їх участю в різних злочинних формуваннях підлітків, впливом на них дорослих підбурювачів та організаторів злочинів, віктимологічний аспект профілактики полягає в заходах, спрямованих на розкладання злочинних груп, виведення підлітків з під впливу підбурювачів, заходи кримінально-правового впливу на підбурювачів та їх ізоляції.

Заходами віктимологічної профілактики щодо об'єктивно не здатних до опору неповнолітніх потерпілих 6 і дії органів поліції, спрямовані на усунення ситуацій, у яких можливі дітовбивства i, зокрема, убивства новонароджених.

У зв'язку з тим, що часто вчинюються сексуальні злочини стосовно неповнолітніх, виникає необхідність здійснення системи заходів, спрямованих на недопущення саме цих злочинів. Специфічність виникнення багатьох з них також, як і особливості особи потерпілих від сексуальних злочинів, створюють певні труднощі в роботі з профілактики цих небезпечних злочинів.

Вихідним моментом труднощів є складність отримання інформації про підготовлювані або вже вчинені щодо неповнолітніх згвалтування, розпусні дії. Причина тому природна скритність злочинців, які не прагнуть оприлюднювати свої задуми і вчинені злочини. Також причиною 6 мовчання потерпілих про те, що відбулося. При цьому потерпілі керуються різними мотивами, а в низці випадків не в змозі правильно оцінити те, що сталося 3 ними [12, с. 202-203].До того ж неповнолітні найчастіше не обізнані про небезпеку, яка їм загрожує навіть тоді, коли злочинець $є$ добре їм знайомою особою. У зазначених випадках поліції мо- 


\section{Кримінальне право, кримінальний процес та криміналістика}

жуть допомогти також бесіди 3 працівниками дошкільних та шкільних дитячих установ, лікарями-педіатрами, працівниками житлових контор (двірниками), тобто особами, які нерідко добре обізнані про негаразди в побуті окремих сімей, стан здоров' дітей тощо. Перевірка отриманих відомостей дає можливість виявити складні «гострі» ситуації, що можуть призвести до вчинення злочину, і вжити профілактичних заходів [13, с. 198-199].

Так, джерелом необхідної інформації можуть стати медичні огляди неповнолітніх (передусім малолітніх дітей), на тілі яких можуть бути виявлені пошкодження чи інші сліди вчинення розпусних дій, згвалтування, залишені злочинцем.

Учителі шкіл, як правило, добре знають дітей, поведінка яких свідчить про ненормальну для їх віку обізнаність в інтимних питаннях, або, навпаки, про скритність, затурканість, найменше розглядають їх як об'єкти можливої уваги сексуального злочинця. Водночас насамперед необхідно враховувати цей віктимологічний аспект можливих моральних відхилень та інформувати про таких підлітків органи поліції. Реальність використання цієї інформаційної можливості багато в чому залежить від того, як організовано взаємодію працівників поліції 3 працівниками шкіл.

Важливе місце в запобіганні статевим злочинам щодо неповнолітніх посідають заходи загального плану, спрямовані на створення умов, що виключають можливість вчинення статевих злочинів. До цих заходів належать «закриття» патрульною службою поліції, добровільними помічниками (дружинниками) місць, у яких найбільш імовірне вчинення таких злочинів: парків, садів, громадських туалетів, дитячих майданчиків, міських і заміських дитячих таборів, територій розташування дошкільних установ тощо.

Використання всього комплексу профілактичних заходів 3 метою запобігання статевим злочинам відносно неповнолітніх має важливе значення. Ці заходи, або точніше, напрями профілактичної роботи слід поділяти на дві умовні групи:
- $з$ використанням зовнішніх можливостей (забезпечення нагляду та захисту потенційних потерпілих);

- 3 використанням внутрішніх можливостей (підвищення здатності потенційних потерпілих до захисту, протидії злочинцю, а також і формування позитивних установок особи).

Засоби масової інформації, публікуючи матеріали про злочини проти дітей, у гонитві за сенсацією нерідко надають такі відомості, які спричиняють додаткову психологічну травму жертвам (потерпілим). Така практика є неприпустимою. Водночас засобам масової інформації слід публікувати більше матеріалів, спрямованих на віктимологічну профілактику злочинів проти дітей і підвищення правової культури населення $[14$, с. $5 ; 15$, с. 150$]$.

Водночас профілактику злочинів можна забезпечити і шляхом активізації самого потенційного потерпілого, підвищення його захисних можливостей, зміцнення волі до самозахисту. Також існуе необхідність інформування даної особи про небезпеку, яка їй загрожує. Якщо спостерігається негативна поведінка можливої жертви, зусилля спрямовуються на нейтралізацію цієї поведінки, що підвищує захисні можливості і знижує віктимність такої особи.

Проведене дослідження дозволяє виділити наступні заходи віктимологічної профілактики сексуальної експлуатації, які проводяться органами Національної поліції України у взаємодії з іншими уповноваженими суб'єктами, а також міжнародними та неурядовими організаціями, представниками громадськості:

1. Аналітично-підготовчі заходи віктимологічної профілактики сексуальної експлуатації:

збір і аналіз інформації про причини та умови, що сприяють протиправній діяльності, пов' язаній з сексуальною експлуатацією. Для цього узагальнюється інформація, отримана при розслідуванні відповідних злочинів, а також одержана від потерпілих. Правоохоронцям доцільно залучати науковців, які проводять дослідження у цій сфері, та журналістів, які вивчають проблематику і здійснюють відповідні професійні розслі- 
дування, а також аналізувати інформацію, якою володіють інші державні органи та неурядові організації;

планування проведення заходів віктимологічної профілактики сексуальної експлуатації із залученням наявних сил і засобів, розробка відповідних допоміжних матеріалів та наповнення їх змістовної частини;

відбір кандидатів для проведення заходів віктимологічної профілактики сексуальної експлуатації, а також їх професійна підготовка, насамперед із залученням можливостей неурядових організацій;

розробка та проведення тренінгів для фахівців, семінарів, круглих столів та конференцій.

2. Інформаційно-просвітницькі заходи, у тому числі з використанням можливостей засобів масової інформації, які проводять як особисто працівники різних правоохоронних органів, так і представники інших органів державної влади та місцевого самоврядування, міжнародних та неурядових організацій:

організація та проведення інформаційних кампаній щодо підвищення рівня обізнаності населення про проблему сексуальної експлуатації та надання порад як уникнути потрапляння до рук зловмисників;

створення та розповсюдження соціальної реклами у сфері запобігання сексуальній експлуатації;

підготовка та розповсюдження за допомогою інформаційних ресурсів (Інтернет, 3МI) відомостей про проблему сексуальної експлуатації, особливо жінками та дітьми як найбільш уразливої категорії населення, а також систематичне оновлення інформації;

підготовка і розсилка, у тому числі за допомогою електронної пошти, новин та інформаційних бюлетенів щодо проблеми сексуальної експлуатації;

розробка, видання та розповсюдження спеціалізованої літератури та навчально-методичних і наукових матеріалів щодо проблеми запобігання сексуальній експлуатації.

3. Превентивна робота в групах з посиленим рівнем віктимності щодо недопущення сексуальної експлуатації:

проведення зустрічей з молоддю, насамперед у навчальних закладах, та доведення інформації про небезпеку стати жертвою сексуальної експлуатації з переконанням дотримуватись порад щодо того, як уникнути подібних ситуацій;

надання консультативної допомоги особам, які вже постраждали від сексуального або фізичного насильства, щодо того, як убезпечити себе від подібної протиправної діяльності в майбутньому.

4. Організація та підтримка роботи «гарячих ліній», за допомогою яких консультуються особи, які можуть стати жертвами сексуальної експлуатації та які вже постраждали від неї, надання їм порад та практичної допомоги в тому, щоб уникнути подібних випадків у майбутньому. Така робота передбачає обмін відповідною інформацією між неурядовими організаціями та органами Національної поліції України. Міжнародний жіночий правозахисний центр «Ла Страда-Україна» забезпечує функціонування Національної гарячої лінії 3 протидії торгівлі людьми, Національної гарячої лінії з протидії домашньому насильству та захисту прав дитини, Електронної гарячої лінії 3 протидії дитячій порнографії в Інтернеті, підтримку в роботі яких надають працівники поліції. Консультації надаються з таких питань:

запобігання торгівлі людьми та різним формам насильства, у тому числі сексуального;

захист прав дітей та потерпілих від насильства людей, у тому числі сексуального;

правильне оформлення документів для виїзду за кордон для працевлаштування, навчання, одруження тощо 3 метою попередження випадків сексуальної експлуатації, а також консультації за допомогою електронної пошти. Аюдина, яка збирається виїхати до іншої країни на заробітки чи з іншими цілями, отримує кваліфіковану допомогу юристів, як належним чином це зробити та убезпечити себе;

надання психологічної допомоги потерпілим від торгівлі людьми та насильства, у тому числі сексуального.

5. Удосконалення основ державної політики у сфері віктимологічної профілактики сексуальної експлуатації, участь у розробці 


\section{Кримінальне право, кримінальний процес та криміналістика}

відповідних проектів міжнародних договорів, законів та підзаконних документів.

6. Вироблення тактики та стратегії здійснення віктимологічної профілактики сексуальної експлуатації на регіональному, загальнонаціональному та міжнародному рівні. Така робота проводиться у співробітництві з закордонними колегами та міжнародними організаціями.

Заходи віктимологічної профілактики сексуальної експлуатації щодо дітей повинні проводитись комплексно та систематично. Саме від цього залежить їх ефективність. Якщо все ж таки дитина стала жертвою сексуальної експлуатації, то потрібно докласти максимум зусиль для того, щоб припинити протиправну діяльність, захистити їі права та надати необхідну медичну, психологічну, матеріальну та іншу допомогу, що, у свою чергу, можна розглядати як складову віктимологічної профілактики сексуальної експлуатації щодо дітей, бо такі заходи впливають на зниження вірогідності повторного потерпання цих осіб від сексуальної експлуатації в майбутньому.

Юридичні особливості надання допомоги та захисту прав жертв сексуальної експлуатації, яка виступає у більшості випадків метою торгівлі людьми, відображені в п'ятому розділі Закону України «Про протидію торгівлі людьми» [16]. Для ефективної допомоги таким особам та їх захисту створюється Національний механізм взаємодії суб'єктів, які здійснюють заходи у сфері протидії торгівлі людьми. Його реалізація включає встановлення потреб постраждалої особи та пошук органів чи закладів, що можуть їх задовольнити. Ці суб'єкти з метою ефективного надання допомоги та захисту постраждалих осіб враховують їх вік, стан здоров’я, стать і спеціальні потреби. Вони взаємодіють між собою та співпрацюють 3 громадськими об'єднаннями, регіональними та міжнародними організаціями.

\section{Лiтература}

1. Джужа А. О. Теоретичні та практичні засади віктимологічного запобігання злочинам в Україні: автореф. дис. докт. юрид. наук: 12.00.08 «Кримінальне право та кримінологія; кримінально-виконавче право».
Харків: Харк. нац. ун-т внутр. справ, 2017. $35 \mathrm{c}$.

2. ВПлив соціально-економічних процесів на злочинність в Україні та у світі (за офіційними матеріалами ООН, Всесвітнього банку, статистичного органу Евросоюзу (Eurostat), Державної служби статистики України): аналітичний огляд. Київ: ДНДІ МВС України, 2018. 26 с.

3. Про зареєстровані кримінальні правопорушення та результати їх досудового розслідування. Генеральна прокуратура України. URL: http://www.gp.gov.ua/ua/stat.html.

4. Методика кримінологічного аналізу злочинності в Україні: навч. посіб. / О. М. Джужа, О. Г. Кулик, В. В. Василевич та ін.; за заг. ред. проф. О. М. Джужі. Київ: Київ. нац. ун-т внутр. справ, 2006. 192 с.

5. Задорожный В. И. Виктимологическая безопасность и ее обеспечение мерами виктимологической профилактики: монография. Тамбов: Першина, 2005. 256 с.

6. Кримінологічна віктимологія: навч. посіб. / E. М. Моiсеєв, О. М. Джужа, В. В. Василевич та ін.; за заг. ред. проф. О. М. Джужі. Київ: Атіка, 2006. 352 с.

7. Джужа О. М., Кирилюк А. В. Пенітенціарна кримінологія та спеціальнопопереджувальна діяльність: загальна частина: навч. посіб. Київ: НВТ «Правник» - НАBСУ, 1997. 117 c.

8. Джужа О. М., Кирилюк А. В. Пенітенціарна кримінологія та спеціальнопопереджувальна діяльність: загальна частина: навч. посіб. Київ: НВТ «Правник» - HABCУ, 1997. 117 c.

9. Victims. The United States Department of Justice. URL: https://search.justice.gov/search?utf $=\% \mathrm{E} 2 \% 9 \mathrm{C} \% 93 \&$ caffiliate $=$ justice $\&$ query $=$ victim

10. Кон И. С. Совращение детей и сексуальное насилие. Педагогика, 1998. № 5. C. 64-66.

11. Кримінологічна віктимологія: навч. посіб. / E. М. Моiсеєв, О. М. Джужа, В. В. Василевич та ін.; за заг. ред. проф. О. М. Джужі. Київ: Атіка, 2006. 352 с.

12. Воронова Ю. В. Соціальнопсихологічні особливості неповнолітніх, які були згвалтовані. Право $і$ безпека. 2004. № 3-4. C. 202-203. 
13. Швед О. В. Комплексна програма реабілітації дітей-жертв сексуальної експлуатації: поетапний аналіз. Право $i$ безпека. 2005. № 4-6. С. 198-199.

14. Косенко С. С. Віктимологічна профілактика статевих злочинів щодо неповнолітніх: автореф. дис. ... канд. юрид наук: спец. 12.00.08 «Кримінальне право та кримінологія; кримінально-виконавче право». Київ: Нац. акад. внутр. справ, 2004. 20 c. C. 5.

15. Иликчиева Е. И. Виктимологическая профилактика сексуального насилля. Боротьба зі злочинністю та права людини: 3б. наук. ст. / за ред. М. П. Орзіха, В. М. Дрьоміна. Одеса: Фенікс, 2006. С. 150.

16. Про протидію торгівлі людьми: Закон від 20 верес. 2011 р. Верховна Рада Украӥни. URL: https://zakon3.rada.gov.ua/laws/ show/3739-17

\section{Віктимологічні заходи запобігання сексуальній експлуатації дитини}

У статті розглянуті віктимологічні питання запобігання сексуальній експлуатації дітей. Наголошено на факторі віктимності, що полягає у здатності потенційних жертв у конкретних життєвих обставинах стати об'єктом злочинного впливу, зазнали фізичних, матеріальних та моральних втрат. 3'ясовано, що заходи віктимологічного запобігання сексуальній експлуатації щодо дітей повинні включати можливості інформаційного впливу на молодіжне середовище 3 пропагуванням здорового способу життя, проведення цільових профілактичних поліцейських заходів, що в комплексі спрямовані на запобігання віктимізації груп неповнолітніх, а також включати індивідуальну роботу з дітьми, які постраждали від сексуального насильства. Виокремлено форми здійснення психопрофілактичної роботи, що мають віктимологічне значення.

Заходи віктимологічної профілактики сексуальної експлуатації щодо дітей повинні проводитись комплексно та систематично. Саме від цього залежить їх ефективність. Якщо все ж таки дитина стала жертвою сексуальної експлуатації, то по- трібно докласти максимум зусиль для того, щоб припинити протиправну діяльність, захистити ії права та надати необхідну медичну, психологічну, матеріальну та іншу допомогу, що, у свою чергу, можна розглядати як складову віктимологічної профілактики сексуальної експлуатації щодо дітей, бо такі заходи впливають на зниження вірогідності повторного потерпання цих осіб від сексуальної експлуатації в майбутньому.

Проведене дослідження дозволило виділити заходи віктимологічної профілактики сексуальної експлуатації, які проводяться органами Національної поліції України у взаємодії з іншими уповноваженими суб'єктами, а також міжнародними та неурядовими організаціями, представниками громадськості: аналітично-підготовчі заходи віктимологічної профілактики сексуальної експлуатації; інформаційно-просвітницькі заходи, у тому числі з використанням можливостей засобів масової інформації, які проводять як особисто працівники різних правоохоронних органів, так і представники інших органів державної влади та місцевого самоврядування, міжнародних та неурядових організацій; превентивна робота в групах з посиленим рівнем віктимності щодо недопущення сексуальної експлуатації; організація та підтримка роботи «гарячих ліній», за допомогою яких консультуються особи, які можуть стати жертвами сексуальної експлуатації та які вже постраждали від неї, надання їм порад та практичної допомоги в тому, щоб уникнути подібних випадків в майбутньому; удосконалення основ державної політики у сфері віктимологічної профілактики сексуальної експлуатації, участь у розробці відповідних проектів міжнародних договорів, законів та підзаконних документів; вироблення тактики та стратегії здійснення віктимологічної профілактики сексуальної експлуатації на регіональному, загальнонаціональному та міжнародному рівні. Така робота проводиться у співробітництві з закордонними колегами та міжнародними організаціями.

Ключові слова: сексуальна експлуатація; віктимологія; жертва; дитина; запобігання. 


\section{Кримінальне право, кримінальний процес та криміналістика}

Victimological measures to prevent sexual exploitation of a child

The article deals with the victimological issues of preventing the sexual exploitation of children. Emphasis is placed on the factor of victimization, which is the ability of potential victims in specific life circumstances to become the object of criminal influence, suffered physical, material and moral loss. It has been found that measures of victimization of sexual exploitation of children should include opportunities for informational influence on the youth environment with promotion of a healthy lifestyle, carrying out targeted preventive police measures in the complex aimed at preventing the victimization of juvenile groups, as well as including individual work. victims of sexual abuse. Forms of realization of psychoprophylactic work having the victimological value are distinguished.

Accelerating the processes of European integration of Ukraine requires the introduction into law enforcement practice not only of modern forms and methods of combating crime, but also of standards recognized by the world community for the protection of human rights and freedoms. Real democratic transformations are integral to the humanization of social relations, for a person, his life and health, honor and dignity, integrity and security are recognized as the highest social value.

Victimological measures for the prevention of sexual exploitation of children should be comprehensive and systematic. This is where their effectiveness depends. If, however, the child is a victim of sexual exploitation, every effort should be made to end the unlawful activity, to protect her rights and to provide the necessary medical, psychological, material and other assistance, which in turn can be considered as a component of victim prevention. sexual exploitation of children, as such measures reduce the likelihood of repeated sexual abuse of such persons in the future.

The conducted research made it possible to identify measures of victimology prevention of sexual exploitation conducted by bodies of the National Police of Ukraine in cooperation with other authorized entities, as well as international and non-governmental organizations, representatives of the public: analytical and preparatory measures of victimological prevention; information and education activities, including the use of media opportunities, which are carried out personally by employees of various law enforcement agencies, as well as representatives of other state and local authorities, international and non-governmental organizations; preventive work in groups with increased levels of victimization regarding the prevention of sexual exploitation; organization and support of hotlines to advise persons who may be victims of sexual exploitation and victims of sexual exploitation, to provide them with advice and practical assistance in avoiding such cases in the future; improvement of the basics of state policy in the sphere of victimization of sexual exploitation, participation in the development of relevant drafts of international treaties, laws and regulations; development of tactics and strategies for victimization of sexual exploitation at the regional, national and international levels. Such work is carried out in cooperation with foreign colleagues and international organizations.

Keywords: sexual exploitation; victimology; victim; child; prevention. 